Vol. 10 (2001): 309-322.

\title{
Composition, ileal amino acid digestibility and nutritive value of organically grown legume seeds and conventional rapeseed cakes for pigs
}

\author{
Kirsi Partanen \\ MTT Agrifood Research Finland, Animal Production Research, Pigs, Tervamäentie 179, \\ FIN-05840 Hyvinkää, Finland, e-mail: kirsi.partanen@mtt.fi \\ Jarmo Valaja, Taina Jalava \\ MTT Agrifood Research Finland, Animal Production Research, Animal Nutrition, \\ FIN-31600 Jokioinen, Finland \\ Hilkka Siljander-Rasi \\ MTT Agrifood Research Finland, Animal Production Research, Pigs, Tervamäentie 179, \\ FIN-05840 Hyvinkää, Finland
}

Eight white-flowered pea (Pisum sativum) and two white-flowered field bean (Vicia faba) cultivars grown organically were analysed for proximate composition and amino acid content. In vivo ileal amino acid digestibilities and faecal energy digestibility were predicted from the in vitro enzymatic digestibility of nitrogen and organic matter, respectively. The crude protein $(\mathrm{CP})$ content of the pea and field bean cultivars ranged from 244 to 279 and from 320 to $347 \mathrm{~g} / \mathrm{kg}$ dry matter (DM), respectively. The concentrations of several essential amino acids in protein decreased as the $\mathrm{CP}$ content increased. In peas, predicted in vivo digestibilities did not correlate with chemical composition, and in field beans were lower than in peas.

A digestibility trial was carried out on six cannulated barrows according to a $6 \times 5$ cyclic changeover design to determine the faecal and ileal nutrient digestibilities of organically grown leafed peas (cv. Sohvi, $199 \mathrm{~g} \mathrm{CP} / \mathrm{kg} \mathrm{DM}$ ), semileafless peas (cv. Karita, $240 \mathrm{~g} \mathrm{CP} / \mathrm{kg} \mathrm{DM}$ ), field beans (cv. Kontu, $320 \mathrm{~g} \mathrm{CP} / \mathrm{kg} \mathrm{DM}$ ), narrow-leafed lupins (Lupinus angustifolius cv. Pershatsvet, $220 \mathrm{~g} \mathrm{CP} / \mathrm{kg} \mathrm{DM}$ ), and conventional warm- and cold-pressed rapeseed cakes (360 and $313 \mathrm{~g} \mathrm{CP} / \mathrm{kg} \mathrm{DM}$, respectively). The net energy contents of the leafed and semileafed peas, field beans, lupins, and cold- and warmpressed rape seed cakes were 10.8, 11.2, 9.8, 9.7, 9.4 and 12.3 MJ/kg DM, respectively. The apparent ileal digestibilities of lysine and threonine were similar, but the digestibility of methionine was poor in all legume seeds. Cystine digestibility was highest in lupins and lowest in field beans. With the exception of phenylalanine, there was no difference in apparent ileal amino acid digestibilities between rapeseed cakes.

Key words: field beans, in vitro digestibility, lupins, organic farming, peas, rapeseed cake

(C) Agricultural and Food Science in Finland

Manuscript received April 2001 


\section{AGRICULTURAL AND FOOD SCIENCE IN FINLAND}

\section{Partanen, K. et al. Organically grown legume seeds and conventional rapeseed cakes for pigs}

\section{Introduction}

In recent years, alternative livestock production methods such as organic farming have been developed to meet the demands of consumers which are concerned about environmental pollution and animal health and welfare in intensive production systems. Organic livestock farming is based primarily on home-grown feedstuffs with the objective of establishing an almost complete on-farm nutrient cycle. In pig feeding, purchased conventional feedstuffs are limited to $20 \%$ of the total amount of annual feed consumption on a dry matter (DM) basis. Moreover, the use of solvent-extracted oil seed meals, e.g. soybean and rapeseed meal, and synthetic amino acids is not allowed (EC 1999). Nitrogen fixating legumes play an important role in the crop rotation of organic farms. In addition, legume seeds, i.e. peas, field beans and sweet lupins, are valuable protein-rich feedstuffs for pigs.

The suitability of different pea cultivars for organic farming has been studied recently. As well as high yield, desirable features for pea cultivars are even maturation, resistance to lodging and high protein content. In monoculture, the lodging percentage is higher in leafed than in semileafless pea cultivars. In mixed cropping, however, leafed cultivars compete better with weeds, and their seeds contain more protein than do those of semileafless cultivars (Niskanen 2000). However, little information is available on the variation in amino acid composition and digestibility in organically grown pea cultivars for pigs. Furthermore, the nutritive value of current field bean cultivars has not been determined.

The crude protein (CP) content of peas $(255 \mathrm{~g} / \mathrm{kg}$ dry matter (DM)), field beans $(300 \mathrm{~g} /$ $\mathrm{kg} \mathrm{DM}$ ) and sweet lupins (320-380 g/kg DM) is intermediate between that of soybean meal and cereals. Compared to soybean meal, the protein of legume seeds, sweet lupins excepted, is rich in lysine. Legume seed protein contains threonine in a similar proportion to that in soybean meal protein; the proportions of sulphur-containing amino acids and tryptophan are, however, lower (Gatel 1994, van Barneveld 1999). Without synthetic amino acid supplementation, cereal-legume seed diets do not meet the protein requirements of pigs. Therefore, rapeseed cake, either organic or conventional, is generally included in organic pig diets. Rapeseed protein is rich in sulphur-containing amino acids and threonine and so complements well the amino acid insufficiency of legume seeds (Castell and Cliplef 1993). However, the fat content of rapeseed cakes can vary greatly, from 100 to $300 \mathrm{~g} / \mathrm{kg} \mathrm{DM}$, depending on the crushing method. Cold-pressed rapeseed cakes with a high fat content are seldom used in conventional pig production and hence little information is available on their digestibility and nutritive value for pigs.

The first objective of this study was to investigate the variation in the chemical composition and amino acid and energy digestibilities of organically grown pea and field bean cultivars for pigs by an in vitro method. The second objective was to determine in vivo the apparent ileal amino acid digestibilities and nutritive value of organically grown grain legumes, i.e. peas, field beans and sweet lupins, and conventional rapeseed cakes for pigs.

\section{Material and methods}

\section{Pea and field bean samples}

The chemical composition and in vitro digestibility of eight white-flowered pea (Pisum sativum) and two white-flowered field bean (Vicia faba) cultivars were evaluated. Seed samples for the pea cultivars (Table 1) were kindly supplied by Mr. Markku Niskanen, MTT Agrifood Research Finland, South Ostrobotnian Research Station, and were grown organically in Ylistaro, Finland, in 1997. The two field bean cultivars, Ukko (Hankkija 1984) and Kontu (Boreal 1997), were obtained from organic farms in Tarvasjoki and Orimattila, Finland, respectively. All samples were ground to pass through a 1-mm sieve 
Vol. 10 (2001): 309-322.

Table 1. Morphological features of seeds derived from pea cultivars.

\begin{tabular}{lclll}
\hline Cultivar & $\begin{array}{c}\text { Weight } \\
\text { g/1000 seeds }\end{array}$ & Coat colour & Leaf type & Height \\
\hline Tiina (Valtion viljavarasto 1993) & 222 & Green & Semileafless & Moderate \\
Sohvi (Jokioinen 1997) & 193 & Green & Leafed & Moderate \\
Sunna (Boreal 1995) & 227 & Yellow & Semileafless & Short \\
Bor 55638 & 209 & Green & Semileafless & Moderate \\
Karita (Svalöf Weibull 1995) & 314 & Green & Semileafless & Moderate \\
Scorpio (Cebeco 1994) & 265 & Yellow & Leafed & Moderate \\
Alfetta (Cebeco 1995) & 289 & Yellow & Semileafless & Short \\
Pika (Hankkija 1987) & 226 & Green & Semileafless & Short \\
\hline
\end{tabular}

${ }^{1}$ Year in which each cultivar was registered for production.

and analysed for proximate composition, amino acid content, and in vitro ileal nitrogen and DM digestibilities and in vitro faecal organic matter digestibility.

\section{Digestibility trial}

Eight growing barrows (seven Finnish Landrace and one Finnish Landrace $\times$ Yorkshire) with an average body weight (BW) of $39 \mathrm{~kg}$ were surgically fitted with a $\mathrm{T}$-shaped silicone cannulae at the caecum according to the post valve T-cannula (PVTC) method (van Leeuwen et al. 1991). Before surgery, the pigs fasted for $36 \mathrm{~h}$ and had no access to water for $12 \mathrm{~h}$. After surgery, the pigs were allowed a $16-\mathrm{d}$ recovery period. To minimise pain, they were injected with Finadyne ( $2.2 \mathrm{mg} / \mathrm{kg} \mathrm{BW}$ i.m., Orion, Finland) for $3 \mathrm{~d}$. To prevent infections, they were injected with Borgal (3 ml/50 kg BW i.m., Hoechst, Germany) for $1 \mathrm{~d}$ and thereafter were given Oriprim $(10 \mathrm{~g} / \mathrm{d}$, Orion, Finland) with their feed for $6 \mathrm{~d}$. During the recovery period, the daily allowance was gradually increased until the pre-surgical level of feed intake was achieved. Water was available ad libitum. The pigs were housed in $1.43 \times$ $1.23-\mathrm{m}$ metabolic pens with slatted plastic floors and transparent plastic sides at an ambient temperature of 20 to $23^{\circ} \mathrm{C}$. One pig died immediately after surgery because of internal bleeding.

The experiment was carried out on six pigs according to a $6 \times 5$ cyclic change-over design
(Davis and Hall 1969). The six experimental treatments were as follows: 1) leafed peas (Pisum sativum cv. Sohvi), 2) semileafless peas (Pisum sativum cv. Karita), 3) field beans (Vicia faba cv. Kontu), 4) narrow-leafed lupins (Lupinus angustifolius cv. Pershatsvet), 5) warm-pressed rapeseed cake (Tupla-Öpex, Mildola, Helsinki) and 6) cold-pressed rapeseed cake (Virgino, Kankaisten Öljykasvit Ltd., Hämeenlinna). The legume seeds were grown organically in 1998, the leafed peas in Vihti, the semileafless peas and field beans in Orimattila and the lupins in Piikkiö, Finland. The composition of the barleybased experimental diets is shown in Table 2 . The barley and legume seeds were ground in a hammer mill to pass through a 4-mm screen (Automatic, Automatic equipment MFG, Pender, Nebrasca, USA). Chromium mordanted straw (93 $\mathrm{g} \mathrm{Cr} / \mathrm{kg} \mathrm{DM}$ ) prepared according to Udèn et al. (1980) was used as an indigestible marker (1.6 $\mathrm{g} / \mathrm{kg}$ feed). The pigs were fed twice daily (0600 and 1800) and were given $100 \mathrm{~g}$ feed $/ \mathrm{kg} \mathrm{BW}^{0.75}$, based on the mean BW of the pigs at the beginning of each period. The feed allowance was kept constant for the whole 14-d period, and adjusted according to the BW at the beginning of each period. Feed was mixed with water $(2 \mathrm{l} / \mathrm{kg}$ feed) immediately before feeding.

There were five 14-d experimental periods. After a 6-d adaptation period, faeces were collected quantitatively for $3 \mathrm{~d}$ according to van Kleef et al. (1994). Thereafter, ileal digesta were collected for a total of $12 \mathrm{~h}$ as follows: on day 
Partanen, K. et al. Organically grown legume seeds and conventional rapeseed cakes for pigs

Table 2. Composition of barley-based experimental diets in the digestibility study.

\begin{tabular}{|c|c|c|c|c|c|c|}
\hline Protein source & $\begin{array}{l}\text { Peas cv. } \\
\text { Sohvi }\end{array}$ & $\begin{array}{l}\text { Peas cv. } \\
\text { Karita }\end{array}$ & $\begin{array}{l}\text { Field beans } \\
\text { cv. Kontu }\end{array}$ & $\begin{array}{l}\text { Lupins cv. } \\
\text { Pershatsvet }\end{array}$ & $\begin{array}{l}\text { Warm- } \\
\text { pressed } \\
\text { rapeseed } \\
\text { cake } \\
5\end{array}$ & $\begin{array}{l}\text { Cold- } \\
\text { pressed } \\
\text { rapeseed } \\
\text { cake } \\
6\end{array}$ \\
\hline \multicolumn{7}{|l|}{ Ingredients, \% } \\
\hline Barley & 42.6 & 42.6 & 65.6 & 42.6 & 65.6 & 65.6 \\
\hline Peas cv. Sohvi & 55.0 & & & & & \\
\hline Peas cv. Karita & & 55.0 & & & & \\
\hline Field beans cv. Kontu & & & 32.0 & & & \\
\hline Lupins cv. Pershatsvet & & & & 55.0 & & \\
\hline $\begin{array}{l}\text { Warm-pressed rapeseed cake } \\
(\text { EE } 101 \mathrm{~g} / \mathrm{kg} \mathrm{DM})\end{array}$ & & & & & 32.0 & \\
\hline $\begin{array}{l}\text { Cold-pressed rapeseed cake } \\
\text { (EE } 239 \mathrm{~g} / \mathrm{kg} \mathrm{DM})\end{array}$ & & & & & & 32.0 \\
\hline Mineral and vitamin premix ${ }^{1}$ & 1.3 & 1.3 & 1.3 & 1.3 & 1.3 & 1.3 \\
\hline Monocalcium phosphate & 0.25 & 0.25 & 0.25 & 0.25 & 0.25 & 0.25 \\
\hline Limestone & 0.85 & 0.85 & 0.85 & 0.85 & 0.85 & 0.85 \\
\hline L-Lysine- $\mathrm{HCl}$ & 0.08 & & 0.11 & 0.19 & & 0.08 \\
\hline DL-Methionine & 0.14 & 0.11 & 0.13 & 0.14 & & \\
\hline \multicolumn{7}{|l|}{ Calculated composition, $\mathrm{g} / \mathrm{kg}$} \\
\hline Crude protein & 142 & 163 & 159 & 159 & 171 & 160 \\
\hline Lysine & 8.2 & 10.0 & 7.9 & 7.1 & 8.9 & 8.2 \\
\hline Methionine and cystine & 4.0 & 4.8 & 4.3 & 4.2 & 7.5 & 6.7 \\
\hline Threonine & 4.7 & 5.8 & 5.3 & 5.4 & 7.4 & 6.8 \\
\hline Calcium & 6.9 & 6.8 & 6.8 & 7.8 & 7.8 & 7.6 \\
\hline Phosphorus & 5.4 & 5.1 & 4.7 & 4.8 & 7.1 & 6.7 \\
\hline
\end{tabular}

$\mathrm{EE}=$ ether extract, $\mathrm{DM}=$ dry matter.

${ }^{1}$ The premix supplied per $\mathrm{kg}$ of feed: $2.3 \mathrm{~g}$ of Ca, $0.8 \mathrm{~g}$ of $\mathrm{P}, 0.5 \mathrm{~g}$ of $\mathrm{Mg}, 3.3 \mathrm{~g}$ of NaCl, $103 \mathrm{mg}$ of Fe, $22 \mathrm{mg}$ of Cu, $91 \mathrm{mg}$ of $\mathrm{Zn}, 23 \mathrm{mg}$ of Mn, $0.28 \mathrm{mg}$ of Se, $0.28 \mathrm{mg}$ of I, $5170 \mathrm{IU}$ of vitamin A, $517 \mathrm{IU}$ of vitamin $\mathrm{D}_{3}, 50 \mathrm{mg}$ of vitamin E, $2 \mathrm{mg}$ of thiamin, $5 \mathrm{mg}$ of riboflavin, $3 \mathrm{mg}$ of pyridoxine, $20 \mu \mathrm{g}$ of vitamin $\mathrm{B}_{12}, 0.2 \mathrm{mg}$ of biotin, $14 \mathrm{mg}$ of pantothenic acid, $20 \mathrm{mg}$ of niacin, $2 \mathrm{mg}$ of folic acid, and $2 \mathrm{mg}$ of vitamin $\mathrm{K}$.

12 from 0600 to 0800,1000 to 1200 , and 1400 to 1600 , and on day 14 from 0800 to 1000,1200 to 1400 , and 1600 to 1800 . The digesta were collected directly into a plastic bag fixed to the cannulae. The plastic bags were removed every $15 \mathrm{~min}$, weighed, and frozen instantly at $-20^{\circ} \mathrm{C}$.

\section{Chemical analyses}

Feed samples and freeze-dried digesta and faecal samples were ground to pass through a 1-mm sieve. Dry matter content was determined by drying at $103^{\circ} \mathrm{C}$ for $16 \mathrm{~h}$. Ash, crude fibre and ether extract (after acid hydrolysis) were determined by standard methods (AOAC 1990). Starch was analysed after ethanol extraction according to Bach Knudsen et al. (1987). Nitrogen was determined by the Dumas method with a Leco FP $428 \mathrm{~N}$ analyser (Leco Corp., St Joseph, USA). Amino acids were analysed according to the official method of the EC (1998). Minerals were determined by ICP emission spectrophotometry (Luh Huang and Schulte 1985) and chromium by atomic absorption spectrophotometry (Williams et al. 1962). In vitro ileal DM and ni- 
Vol. 10 (2001): 309-322.

trogen digestibilities were determined according to Boisen and Fernández (1995) and in vitro faecal organic matter digestibility according to Boisen and Fernández (1997).

\section{Calculations and statistical analysis}

The in vivo ileal digestibilities of nitrogen and amino acids were predicted from in vitro nitrogen and dry matter digestibilities as described by Boisen and Fernández (1995) and the in vivo faecal digestibility of energy was predicted from in vitro organic matter digestibility according to Boisen and Fernández (1997). Correlation coefficients were calculated between proximate composition and amino acid composition and digestibility coefficients by the CORR procedure of SAS (SAS 1998).

Apparent ileal and total tract digestibilities were calculated using chromium as an indigestible marker as follows:

Apparent ileal or total tract digestibility

$$
=\left[(\mathrm{N} / \mathrm{Cr})_{\mathrm{d}}-(\mathrm{N} / \mathrm{Cr})_{\mathrm{f}}\right] /(\mathrm{N} / \mathrm{Cr})_{\mathrm{d}}
$$

where $(\mathrm{N} / \mathrm{Cr})_{\mathrm{d}}=$ the dietary ratio of nutrient to $\mathrm{Cr}$ and $(\mathrm{N} / \mathrm{Cr})_{\mathrm{f}}=$ the ratio of nutrient to $\mathrm{Cr}$ in faeces or ileal digesta. The digestibilities of the investigated protein feedstuffs were calculated by difference using previously determined digestibility coefficients for barley (Valaja et al. 1999). It was assumed that synthetic amino acids were completely absorbed in the small intestine. The net energy content of protein feedstuffs was calculated from chemical composition and determined faecal digestibility coefficients according to Tuori et al. (1996).

Statistical analysis of digestibility data was carried out using the GLM procedure of SAS (SAS 1998) and the following model (Snedecor and Cochran 1989): $Y_{i j k}=\mu+A_{i}+P_{j}+D_{k}+e_{i j k}$, where A, P and D are effects of animal, period and dietary treatment, respectively. Residuals were checked for normality and plotted against fitted values. Differences between treatments were tested with the Tukey test when appropriate.

\section{Results and discussion}

\section{Chemical composition and in vitro digestibility of pea and field bean cultivars}

The chemical composition and in vitro digestibilities of the eight organically grown pea and two field bean cultivars studied is presented in Tables 3 and 4, respectively. The average CP content of the pea cultivars $(254 \pm 11.7 \mathrm{~g} / \mathrm{kg} \mathrm{DM})$ is similar to values reported recently for whiteflowered peas (Gdala et al. 1992, Igbasan et al. 1997, Fan and Sauer 1999). The protein content of peas is known to vary greatly both between and within cultivars, as shown in the reviews of Savage and Deo (1989) and Gatel and Grosjean (1990), who reported CP ranges from 156 to 325 and from 181 to $346 \mathrm{~g} / \mathrm{kg}$ DM, respectively. Here, the leafed cultivars, Sohvi and Scorpio, had a higher CP content than did the semileafless ones $(271 \pm 8$ vs. $248 \pm 3.4 \mathrm{~g} / \mathrm{kg} \mathrm{DM})$, a finding that is in agreement with the results of official variety trials carried out in Finland (Järvi et al. 2000). The variations in CP content were not related to seed colour, since green- and yellow-seeded cultivars had similar average protein contents $(255 \pm 12.6$ vs. $253 \pm 7.5 \mathrm{~g} / \mathrm{kg} \mathrm{DM})$. There was also no correlation between protein content and seed size (Table 5), which confirms the results of Igbasan et al. (1997). Both ether extract and crude fibre contents were low in pea cultivars, as found previously (Savage and Deo 1989, Gatel and Grosjean 1990). The crude fibre content increased $(\mathrm{r}=0.73)$ and the ether extract content decreased $(r=-0.74)$ with $\mathrm{CP}$ content. Field bean cultivars contained more $\mathrm{CP}$ and crude fibre than did peas, but the ether extract content was similar to that of peas. The higher fibre content of beans is probably due to the higher proportion of hulls in their seeds than in those of peas. The proportion of hulls in pea cultivars has ranged from 8.0 to $12.0 \%$ of total seed weight (Igbasan et al. 1997) and that of field beans from 10.5 to $15.5 \%$ (Brufau et al. 1998).

The concentrations of several essential amino acids (expressed as $\mathrm{g} / 16 \mathrm{~g} \mathrm{~N}$ ) varied among 
Partanen, K. et al. Organically grown legume seeds and conventional rapeseed cakes for pigs
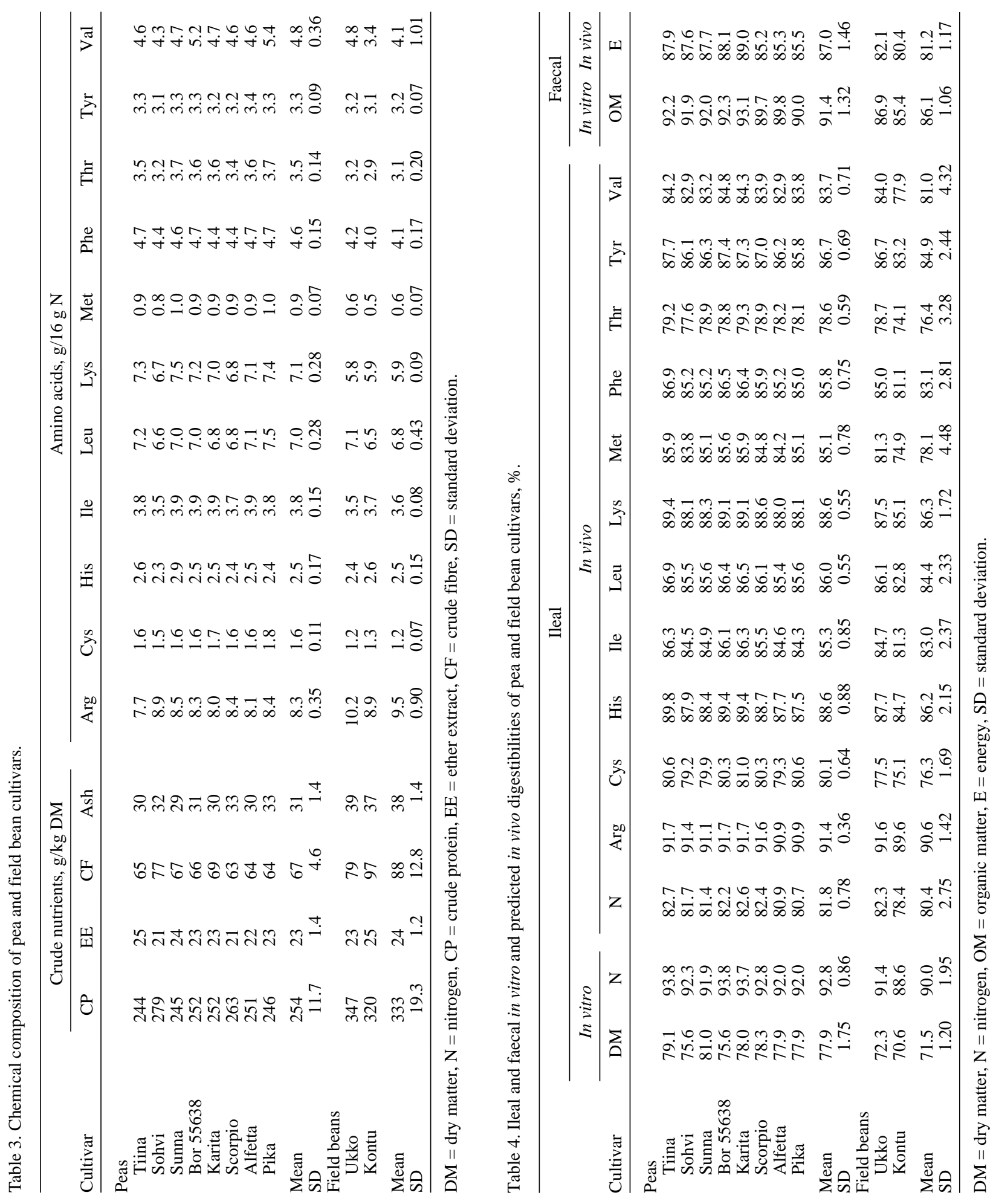
Vol. 10 (2001): 309-322.

the pea and field bean cultivars (Table 3 ). There was no evidence to show that this variation was related to seed weight or colour. The protein of semileafless pea cultivars contained more lysine and other essential amino acids than did that of leafed pea cultivars. This could be explained by the lower CP content in the former. Previous studies have shown that amino acid concentrations in pea protein are negatively correlated with pea protein content (Gatel and Grosjean 1990, Igbasan et al. 1997) and the same observation was made in this study (Table 5). Only arginine $(\mathrm{r}=0.71)$ had a positive correlation with protein content. Field bean protein contained less lysine, methionine, cystine and threonine than did pea protein, which is consistent with the studies reviewed by Gatel (1994). Of the non-essential amino acids, the average concentrations of alanine, aspartic acid, glutamic acid, glycine, proline, and serine were slightly higher for pea than for field bean protein (results not shown). In this study, only two field bean cultivars were evaluated, and thus no conclusions can be drawn about the relationship between $\mathrm{CP}$ and amino acid contents in field beans. According to Gatel (1994), the proportions of essential amino acids, particularly those of lysine, sulphur-containing amino acids, tryptophan and threonine, decrease in field bean protein as protein content of seeds increases. The concentration of amino acids in legume seed protein is a function of the amino acid composition of the storage proteins, albumins and globulins. The albumin is relatively rich in sulphur-containing amino acids (Casey et al. 1993). The bulk of the pea and field bean seed protein comprises, however, globulins, i.e. legumin, vicilin and convicilin, which have low content of sulphur-containing amino acids.

The pea cultivars showed little variation in in vitro nitrogen and organic matter digestibilities and the respective predicted in vivo ileal amino acid and faecal energy digestibilities (Table 4). Boisen and Fernández (1995) reported an in vitro nitrogen digestibility of $95.6 \%$ for peas, which is slightly higher than that observed in this study. Boisen and Fernández (1997) reported an in vitro organic matter digestibility of $89.3 \%$ and
Table 5. Relationship between crude protein content and chemical composition and in vitro and predicted in vivo digestibilities in peas $(n=8)$.

\begin{tabular}{lcc}
\hline & \multicolumn{2}{c}{ Crude protein, g/kg DM } \\
\cline { 2 - 3 } & $r$ & $\mathrm{P} \leq$ \\
\hline Seed weight, g/1000 seeds & -0.23 & 0.59 \\
Ether extract, g/kg DM & -0.74 & 0.04 \\
Crude fibre, g/kg DM & 0.73 & 0.04 \\
Ash, g/kg DM & 0.45 & 0.26 \\
Amino acids, g/16 g N & & \\
Arginine & 0.71 & 0.05 \\
Cystine & -0.66 & 0.07 \\
Histidine & -0.65 & 0.08 \\
Isoleucine & -0.88 & 0.01 \\
Leucine & -0.77 & 0.03 \\
Lysine & -0.86 & 0.01 \\
Methionine & -0.86 & 0.01 \\
Phenylalanine & -0.79 & 0.02 \\
Threonine & -0.93 & 0.001 \\
Tyrosine & -0.75 & 0.03 \\
Valine & -0.51 & 0.19 \\
Ileal digestibility, \% & & \\
Dry matter in vitro & -0.62 & 0.10 \\
N in vitro & -0.14 & 0.74 \\
N predicted in vivo & 0.11 & 0.79 \\
Faecal digestibility, \% & & \\
Organic matter in vitro & -0.04 & 0.92 \\
Energy predicted in vivo & -0.04 & 0.92 \\
\hline
\end{tabular}

$\mathrm{DM}=$ dry matter, $\mathrm{N}=$ nitrogen.

predicted an in vivo faecal energy digestibility of $84.1 \%$ for peas. These values are lower than those observed here. In peas, the predicted digestibility coefficients did not correlate with proximate composition or seed weight. The predicted in vivo digestibilities were higher than those reported for different pea cultivars in in vivo studies (Gdala et al. 1992, Fan and Sauer 1994, 1999). This is in agreement with the results of Cone and van der Poel (1993), who used a two-step in vitro method (pepsin- $\mathrm{HCl}$ digestion followed by pancreatin and a-amylase digestion) to predict the in vivo digestibility of different pea cultivars. They found no linear relationship between the in vivo and in vitro digestibility of pea samples. Here, lower predicted in vivo ileal amino acid digestibilities were 


\section{Partanen, K. et al. Organically grown legume seeds and conventional rapeseed cakes for pigs}

found in field beans than in peas, particularly for sulphur-containing amino acids. In addition, the predicted in vivo faecal digestibility of energy was lower in the former. This confirms with the findings of previous in vivo digestibility studies (Gatel 1994).

\section{Digestibility trial}

The pigs remained healthy and consumed their feed allowances throughout the experiment. One pig was removed from the trial in the last period because its cannula came off. Postmortem examinations, carried out at the conclusion of the experiment, revealed no intestinal adhesions or other abnormalities.

The chemical composition of the legume seeds and rapeseed cakes investigated in the digestibility trial are given in Table 6 . The proximate composition of legume seeds was within the range reported in the literature (Gatel 1994, van Barneveld 1999). The CP contents of leafed peas and lupins were lower than was expected from the results of cultivation trials (Mehto 1986, Järvi et al. 2000). The CP content of the leafed pea cultivar, Sohvi, was only $199 \mathrm{~g} / \mathrm{kg}$ DM whereas it was $279 \mathrm{~g} / \mathrm{kg}$ DM in the sample used in the in vitro trial, which was grown in 1997. The 1998 growing season was cool and rainy, which may have influenced plant maturation and thus the chemical composition of seeds, particularly the protein content (Savage and Deo 1989, Wasilewko and Buraczewska 1999). The carbohydrate composition of lupins differed from that of peas and field beans, with negligible levels of starch and a high level of crude fibre. Lupin seeds are particularly rich in hemicellulose when compared to peas and field beans (van Barneveld 1999). The amino acid concentrations of pea, field bean and lupin seed protein were in the range of values observed in the in vitro trial and reported in the literature (Igbasan et al. 1997, Brufau et al. 1998, Wasilewko and Buraczewska 1999). The concentration of lysine in protein was highest in peas, followed by field beans and lupins. The methionine content was relatively low in all legume seeds. In the pea cultivars Karita and Sohvi, it was lower than in the samples used in the in vitro trial. It was not possible to obtain a result for in vitro ileal digestibility of nitrogen and DM for legume seeds; because of the viscosity, the legume seed samples did not filtrate after enzymatic digestion. This difficulty in the filtering could have been caused by the incomplete degradation of starch by pancreatin and/or pectins present in legume seeds. The in vitro faecal organic matter digestibilities of peas and field beans were within the range of values determined in the in vitro trial (Table 6).

The ether extract content in cold-pressed rapeseed cake was very high, over twice that in warm-pressed rapeseed cake. Consequently, the $\mathrm{CP}$ content was lower in the former. Nyström et al. (1996) tested the nutritive value of rapeseed cakes from a large oil mill. After the prepressing stage, the fat content amounted to $232 \mathrm{~g} / \mathrm{kg}$ $\mathrm{DM}$, whereas the final heat-pressure-moisturetreated product contained $118 \mathrm{~g}$ crude fat $/ \mathrm{kg} \mathrm{DM}$. Keith and Bell (1991) reported ether extract contents of 212 and $39 \mathrm{~g} / \mathrm{kg}$ DM for rapeseed press cake and solvent-extracted rapeseed meal. In the protein of rapeseed cakes, the concentrations of all amino acids, except lysine, were similar. The lower lysine content in warm-pressed rapeseed cake may have been caused by heat applied during the crushing process (Nyström et al. 1996). Lysine concentrations were lower than previously reported for protein in rapeseed cake (Keith and Bell 1991). Otherwise, the chemical composition was in the range of values reported previously for rapeseed cakes (Keith and Bell 1991, Nyström et al. 1996).

The faecal nutrient digestibilities of legume seeds and rapeseed cakes calculated by difference are shown in Table 7. Faecal organic matter digestibility was higher in legume seeds than in rapeseed cakes $(\mathrm{P}<0.05)$. Among legume seeds, the faecal digestibility of organic matter was higher in peas than in field beans or lupins $(\mathrm{P}<0.05)$. The faecal CP digestibility was highest in the pea cultivar Karita and lowest in the warm-pressed rapeseed cake. The faecal CP digestibility of the pea cultivars is in the range of 
Vol. 10 (2001): 309-322.

Table 6. Analysed composition of barley and protein feedstuffs, g/kg dry matter unless stated otherwise.

\begin{tabular}{|c|c|c|c|c|c|c|c|}
\hline & Barley & $\begin{array}{c}\text { Peas cv. } \\
\text { Sohvi }\end{array}$ & $\begin{array}{c}\text { Peas cv. } \\
\text { Karita }\end{array}$ & $\begin{array}{c}\text { Field beans } \\
\text { cv. Kontu }\end{array}$ & $\begin{array}{l}\text { Lupins cv. } \\
\text { Pershatsvet }\end{array}$ & $\begin{array}{l}\text { Warm- } \\
\text { pressed } \\
\text { rapeseed } \\
\text { cake }\end{array}$ & $\begin{array}{l}\text { Cold- } \\
\text { pressed } \\
\text { rapeseed } \\
\text { cake }\end{array}$ \\
\hline Dry matter, g/kg & 882.5 & 896.3 & 888.3 & 877.1 & 902.3 & 909.1 & 913.9 \\
\hline Ash & 27.4 & 32.0 & 29.2 & 37.0 & 44.9 & 70.3 & 59.8 \\
\hline Crude protein & 116.3 & 199.3 & 239.9 & 319.6 & 219.9 & 359.7 & 313.0 \\
\hline Ether extract & 29.3 & 32.3 & 27.3 & 25.1 & 81.2 & 101.3 & 238.6 \\
\hline Crude fibre & 58.7 & 84.9 & 50.4 & 97.4 & 206.1 & 133.2 & 104.3 \\
\hline Starch & 605.3 & 483.3 & 490.3 & 422.5 & 63.9 & 55.7 & 30.8 \\
\hline Calcium & 0.66 & 0.96 & 0.93 & 1.37 & 5.74 & 7.51 & 6.31 \\
\hline Phosphorus & 3.73 & 4.31 & 4.89 & 6.84 & 5.73 & 12.32 & 10.37 \\
\hline Magnesium & 1.27 & 1.48 & 1.32 & 1.60 & 2.36 & 5.56 & 4.13 \\
\hline Potassium & 6.23 & 11.21 & 11.26 & 11.97 & 11.06 & 14.36 & 11.70 \\
\hline Sodium & 0.15 & 0.13 & 0.11 & 0.19 & 0.19 & 0.06 & 0.11 \\
\hline Iron, mg/kg DM & 24.40 & 34.30 & 22.18 & 38.26 & 32.43 & 45.54 & 34.18 \\
\hline Copper, mg/kg DM & 4.03 & 6.52 & 7.12 & 21.14 & 5.80 & 4.80 & 3.77 \\
\hline Zinc, $\mathrm{mg} / \mathrm{kg}$ DM & 27.37 & 35.73 & 24.94 & 45.93 & 43.80 & 52.89 & 51.69 \\
\hline Manganese, $\mathrm{mg} / \mathrm{kg} \mathrm{DM}$ & 14.78 & 13.10 & 12.44 & 17.48 & 40.10 & 60.49 & 52.38 \\
\hline \multicolumn{8}{|l|}{ Amino acids, g/16 g N } \\
\hline \multicolumn{8}{|l|}{ Essential } \\
\hline Arginine & 5.4 & 7.9 & 7.9 & 8.9 & 8.6 & 6.0 & 6.0 \\
\hline Histidine & 2.7 & 2.6 & 2.9 & 2.6 & 2.6 & 2.9 & 2.8 \\
\hline Isoleucine & 3.3 & 4.3 & 4.2 & 3.7 & 4.7 & 3.9 & 4.1 \\
\hline Leucine & 6.3 & 6.6 & 6.6 & 6.5 & 5.9 & 6.5 & 6.4 \\
\hline Lysine & 3.9 & 7.2 & 7.1 & 5.9 & 4.8 & 5.0 & 5.8 \\
\hline Methionine & 1.5 & 0.8 & 0.7 & 0.5 & 0.7 & 1.9 & 1.8 \\
\hline Phenylalanine & 4.7 & 4.8 & 4.8 & 4.0 & 3.5 & 4.5 & 4.1 \\
\hline Threonine & 3.5 & 3.4 & 3.3 & 2.9 & 2.9 & 4.2 & 4.3 \\
\hline Valine & 4.2 & 3.7 & 3.9 & 3.4 & 3.8 & 4.6 & 4.4 \\
\hline \multicolumn{8}{|l|}{ Non-essential } \\
\hline Alanine & 4.3 & 4.5 & 4.5 & 4.0 & 3.6 & 4.3 & 4.3 \\
\hline Aspartic acid & 6.0 & 10.1 & 10.3 & 9.2 & 8.3 & 6.8 & 7.3 \\
\hline Cystine & 2.5 & 1.7 & 1.5 & 1.3 & 1.7 & 1.8 & 2.0 \\
\hline Glutamic acid & 22.2 & 16.7 & 17.1 & 15.6 & 19.5 & 17.0 & 16.4 \\
\hline Glycine & 4.3 & 4.4 & 4.3 & 3.9 & 3.9 & 5.1 & 5.1 \\
\hline Proline & 9.7 & 4.1 & 4.9 & 4.2 & 4.6 & 6.0 & 5.8 \\
\hline Serine & 4.3 & 4.6 & 4.7 & 4.3 & 4.4 & 4.2 & 4.2 \\
\hline Tyrosine & 3.4 & 3.4 & 3.3 & 3.1 & 3.2 & 3.3 & 3.2 \\
\hline \multicolumn{8}{|l|}{ In vitro digestibility } \\
\hline DM ileal & 75.5 & n.r. & n.r. & n.r. & n.r. & 53.8 & 62.8 \\
\hline $\mathrm{N}$ ileal & 84.6 & n.r. & n.r. & n.r. & n.r. & 80.6 & 83.6 \\
\hline OM faecal & 83.9 & 90.1 & 93.3 & 85.4 & 78.8 & 75.6 & 82.2 \\
\hline
\end{tabular}

$\mathrm{DM}=$ dry matter, $\mathrm{N}=$ nitrogen.

n.r. $=$ no result due to difficulty filtering the enzymatically digested sample.

values reported previously (Gdala et al. 1992, Jondreville et al. 1992, Helander et al. 1996). The faecal digestibility of CP was higher in semileafless than in leafed peas $(\mathrm{P}>0.05)$. The crude fibre content was higher in leafed than in semi- leafless peas, which may be one reason for the poorer protein digestibility of the former. A high fibre content has been reported to have an adverse effect on CP digestibility in peas (Gdala et al. 1992). Tannins are also known to have an 
Partanen, K. et al. Organically grown legume seeds and conventional rapeseed cakes for pigs

Table 7. Apparent total tract and ileal digestibilities of grain legumes and rape seed expellers calculated by difference.

\begin{tabular}{|c|c|c|c|c|c|c|c|c|}
\hline Protein source & $\begin{array}{c}\text { Peas cv. } \\
\text { Sohvi }\end{array}$ & $\begin{array}{c}\text { Peas cv. } \\
\text { Karita }\end{array}$ & $\begin{array}{c}\text { Field } \\
\text { beans } \\
\text { cv. Kontu }\end{array}$ & $\begin{array}{l}\text { Lupins cv. } \\
\text { Pershatsvet }\end{array}$ & $\begin{array}{l}\text { Warm- } \\
\text { pressed } \\
\text { rapeseed } \\
\text { cake }\end{array}$ & $\begin{array}{l}\text { Cold- } \\
\text { pressed } \\
\text { rapeseed } \\
\text { cake }\end{array}$ & $\sqrt{\mathrm{MSE}}$ & $\begin{array}{c}\mathrm{F} \\
\mathrm{P} \leq\end{array}$ \\
\hline Observations & 5 & 5 & 5 & 4 & 5 & 5 & & \\
\hline \multicolumn{9}{|l|}{ Faecal digestibility, $\%$} \\
\hline Organic matter & $89.4^{\mathrm{a}}$ & $93.3^{\mathrm{a}}$ & $81.5^{\mathrm{b}}$ & $78.2^{\mathrm{b}}$ & $69.5^{\mathrm{c}}$ & $71.0^{c}$ & 1.07 & 0.001 \\
\hline Crude protein & $77.9^{\mathrm{bc}}$ & $85.7^{\mathrm{a}}$ & $81.7^{\mathrm{ab}}$ & $77.2^{\mathrm{bc}}$ & $74.1^{\mathrm{c}}$ & $77.6^{\mathrm{bc}}$ & 1.07 & 0.001 \\
\hline Ether extract & $50.6^{\mathrm{bc}}$ & $44.3^{\mathrm{c}}$ & $67.0^{\mathrm{a}}$ & $65.7^{\mathrm{ab}}$ & $80.4^{\mathrm{a}}$ & $78.5^{\mathrm{a}}$ & 3.05 & 0.001 \\
\hline Crude fibre & $70.1^{\mathrm{ab}}$ & $81.5^{\mathrm{a}}$ & $27.8^{\mathrm{c}}$ & $60.1^{\mathrm{b}}$ & $38.4^{\mathrm{c}}$ & $34.5^{\mathrm{c}}$ & 3.73 & 0.001 \\
\hline Nitrogen free extract & $98.2^{\mathrm{a}}$ & $99.7^{\mathrm{a}}$ & $94.5^{\mathrm{ab}}$ & $90.3^{\mathrm{b}}$ & $77.2^{\mathrm{c}}$ & $74.2^{\mathrm{c}}$ & 1.25 & 0.001 \\
\hline \multicolumn{9}{|c|}{ Apparent ileal digestibility, $\%$} \\
\hline Organic matter & $62.7^{\mathrm{a}}$ & $65.4^{\mathrm{a}}$ & $65.4^{\mathrm{a}}$ & $38.9^{\mathrm{b}}$ & $54.0^{\mathrm{ab}}$ & $56.9^{\mathrm{ab}}$ & 3.84 & 0.01 \\
\hline Crude protein & 67.2 & 68.6 & 64.9 & 73.6 & 64.8 & 61.5 & 2.53 & 0.11 \\
\hline Ether extract & $54.5^{\mathrm{cd}}$ & $46.2^{\mathrm{d}}$ & $66.9^{\mathrm{abc}}$ & $63.3^{\text {bcd }}$ & $84.6^{\mathrm{a}}$ & $78.4^{\mathrm{ab}}$ & 3.84 & 0.001 \\
\hline \multicolumn{9}{|l|}{ Essential amino acids } \\
\hline Arginine & $82.2^{\mathrm{bc}}$ & $85.4^{\mathrm{ab}}$ & $84.0^{\mathrm{b}}$ & $89.6^{\mathrm{a}}$ & $82.6^{\mathrm{bc}}$ & $78.5^{\mathrm{c}}$ & 1.08 & 0.001 \\
\hline Histidine & 73.4 & 78.9 & 72.4 & 77.6 & 78.9 & 76.0 & 1.48 & 0.03 \\
\hline Isoleucine & $69.0^{\mathrm{b}}$ & $73.3^{\mathrm{ab}}$ & $66.2^{\mathrm{b}}$ & $81.1^{\mathrm{a}}$ & $71.3^{\mathrm{ab}}$ & $65.3^{\mathrm{b}}$ & 2.28 & 0.01 \\
\hline Leucine & $66.0^{\mathrm{bc}}$ & $72.4^{\mathrm{ab}}$ & $68.9^{\mathrm{abc}}$ & $76.8^{\mathrm{a}}$ & $70.5^{\mathrm{abc}}$ & $64.7^{\mathrm{c}}$ & 1.63 & 0.01 \\
\hline Lysine & $77.7^{\mathrm{a}}$ & $79.4^{\mathrm{a}}$ & $75.8^{\mathrm{ab}}$ & $76.8^{\mathrm{ab}}$ & $68.3^{\mathrm{b}}$ & $72.2^{\mathrm{ab}}$ & 1.78 & 0.01 \\
\hline Methionine & $37.5^{\mathrm{b}}$ & $35.1^{\mathrm{b}}$ & $13.8^{\mathrm{c}}$ & $30.0^{\mathrm{bc}}$ & $71.6^{\mathrm{a}}$ & $62.0^{\mathrm{a}}$ & 4.30 & 0.001 \\
\hline Phenylalanine & $67.2^{\mathrm{ab}}$ & $73.5^{\mathrm{a}}$ & $64.5^{\mathrm{ab}}$ & $70.5^{\mathrm{ab}}$ & $73.3^{\mathrm{a}}$ & $63.6^{\mathrm{b}}$ & 2.04 & 0.01 \\
\hline Threonine & 57.0 & 62.0 & 57.7 & 67.4 & 65.4 & 60.8 & 2.91 & 0.18 \\
\hline Valine & $52.3^{\mathrm{b}}$ & $61.3^{\mathrm{ab}}$ & $55.3^{\mathrm{b}}$ & $68.6^{\mathrm{a}}$ & $61.2^{\mathrm{ab}}$ & $53.0^{\mathrm{b}}$ & 2.11 & 0.01 \\
\hline \multicolumn{9}{|c|}{ Non-essential amino acids } \\
\hline Alanine & $63.8^{\mathrm{ab}}$ & $69.0^{\mathrm{a}}$ & $59.5^{\mathrm{b}}$ & $70.1^{\mathrm{a}}$ & $68.6^{\mathrm{a}}$ & $64.9^{\mathrm{ab}}$ & 1.82 & 0.01 \\
\hline Aspartic acid & $68.7^{\mathrm{ab}}$ & $75.5^{\mathrm{a}}$ & $73.7^{\mathrm{a}}$ & $77.6^{\mathrm{a}}$ & $63.9^{\mathrm{b}}$ & $62.8^{\mathrm{b}}$ & 1.84 & 0.001 \\
\hline Cystine & $52.6^{\mathrm{b}}$ & $57.8^{\mathrm{ab}}$ & $47.3^{\mathrm{b}}$ & $71.4^{\mathrm{a}}$ & $58.1^{\mathrm{ab}}$ & $58.4^{\mathrm{ab}}$ & 3.54 & 0.01 \\
\hline Glutamic acid & $77.2^{\mathrm{abc}}$ & $80.8^{\mathrm{ab}}$ & $70.0^{\mathrm{c}}$ & $85.4^{\mathrm{a}}$ & $77.9^{\mathrm{ab}}$ & $73.1^{\mathrm{bc}}$ & 1.68 & 0.001 \\
\hline Glycine & $52.6^{\mathrm{b}}$ & $60.5^{\mathrm{ab}}$ & $52.9^{\mathrm{b}}$ & $67.5^{\mathrm{a}}$ & $65.9^{\mathrm{a}}$ & $63.4^{\mathrm{ab}}$ & 2.73 & 0.01 \\
\hline Proline & $60.8^{\mathrm{ab}}$ & $79.2^{\mathrm{a}}$ & $49.3^{\mathrm{b}}$ & $90.3^{\mathrm{a}}$ & $77.7^{\mathrm{a}}$ & $82.8^{\mathrm{a}}$ & 6.04 & 0.01 \\
\hline Serine & $63.8^{\mathrm{ab}}$ & $70.5^{\mathrm{a}}$ & $59.7^{\mathrm{b}}$ & $73.0^{\mathrm{a}}$ & $62.6^{\mathrm{ab}}$ & $56.4^{\mathrm{b}}$ & 2.11 & 0.001 \\
\hline Tyrosine & 63.2 & 70.0 & 62.3 & 72.1 & 72.4 & 61.0 & 2.74 & 0.03 \\
\hline
\end{tabular}

$\sqrt{ } \mathrm{MSE}=$ root mean square error.

a, b, c, d Means within the same row followed by the same letters do not differ significantly $(\mathrm{P} \geq 0.05)$.

adverse effect on faecal protein digestibility, but their content is generally low in white-flowered peas (Gatel and Grosjean 1990, Gdala et al. 1992). Among legume seeds, the faecal digestibility of CP was lowest in lupins, lower than in the semileafless pea cultivar, Karita $(P<0.05)$. The faecal digestibility of $\mathrm{CP}$ in field beans was similar to that of peas $(\mathrm{P}>0.05)$, and is in agreement with results reviewed by Gatel (1994).

In peas, the faecal digestibility of ether extract was lower than in the study of Helander et al. (1996), who reported a faecal ether extract digestibility of $58.0 \%$ for Pika, a semileafless pea cultivar. The faecal digestibility of crude fibre was considerably higher in peas (70.1$81.5 \%)$ and sweet lupins $(60.1 \%)$ than in field beans $(27.8 \%)$. Both peas and sweet lupins contain only a small amount of lignin and thus the digestibility of the fibre fraction is high (Gdala et al. 1992, van Barneveld 1999). The calculated net energy contents $(\mathrm{MJ} / \mathrm{kg} \mathrm{DM})$ of legume seeds were 10.8 for leafed peas, 11.2 for semi- 
Vol. 10 (2001): 309-322.

leafless peas, 9.8 for field beans and 9.7 for $1 u-$ pins. The faecal nutrient digestibilities of warmand cold-pressed rapeseed cakes did not differ significantly. The faecal digestibility of ether extract was higher than in legume seeds, whereas the crude fibre digestibility was lower than in peas and lupins $(\mathrm{P}<0.05)$, but did not differ from that in field beans $(\mathrm{P}>0.05)$. The determined faecal digestibilities of rapeseed cakes are in the range of values reported previously (Keith and Bell 1991, Schöne et al. 1996). The cold-pressed rapeseed cake was energetically richer than the warm-pressed type (12.3 vs. 9.4 MJ NE/kg DM). This difference in net energy content was primarily due to differences in crude fat content, because there was no difference in faecal nutrient digestibilities between the rapeseed cakes.

The apparent ileal amino acid digestibilities are presented in Table 7. The ileal digestibilities of lysine, threonine, histidine, phenylalanine, tyrosine and aspartic acid did not differ between legume seeds $(\mathrm{P}>0.05)$. The ileal digestibilities of arginine, isoleucine, valine and most of the non-essential amino acids were highest in sweet lupins and lowest in field beans. The greatest differences in ileal amino acid digestibility occurred for methionine and cystine. The apparent ileal digestibility of amino acids has varied greatly among pea cultivars. In recent studies (Jondreville et al. 1992, Fan and Sauer 1994, 1999), lysine digestibility has ranged from $66 \%$ to $85 \%$, threonine digestibility from $60 \%$ to $77 \%$, methionine digestibility from $69 \%$ to 79 , and cystine digestibility from $54 \%$ to $66 \%$. In general, the apparent ileal digestibility of methionine was very low in all legume seeds, whereas cystine digestibility was higher in lupins than in peas or field beans. The low content and poor digestibility of sulphur-containing amino acids in legume seeds makes the formulation of organic pig diets based on on-farm feedstuffs difficult. The very low apparent methionine digestibility of legume seeds may be due to the antinutritive factors and carbohydrates present in the seeds. Le Guen et al. (1995) observed considerably lower apparent methionine digestibility in raw peas
(34-48\%) than in pea protein isolates $(65-75 \%)$ which contained small amounts of antinutritive factors and were free of pea carbohydrates. Raw peas contain pea pectins and cell walls, which increase endogenous protein secretion. Furthermore, the alpha-calactosides and pectins present in peas may stimulate bacterial fermentation. Unfavourable growing conditions may be yet another factor responsible for poor digestibility (Savage and Deo 1989).

The apparent ileal digestibility of field bean protein was lower here than the range of values (72-89\%) reviewed by Gatel (1994). Reports on the apparent ileal amino acid digestibility of field beans are, however, scarce. The apparent ileal amino acid digestibilities of narrow-leafed lupins were lower than those reported by Fernández and Batterham (1995). In their trials, the apparent ileal digestibility of protein was 69$85 \%$, that of lysine $81-82 \%$, that of threonine $74-75 \%$ and that of methionine $81-96 \%$. In their reviews, Gatel (1994) and van Barneveld (1999) reported apparent ileal amino acid digestibilities of $80-88 \%$ for lysine, and $62-77 \%$ for methionine and threonine. Despite their high crude fibre content, lupin seed protein and amino acids seem to be digested equally well, if not better, in the ileum than those of peas and field beans. There was no difference in the digestibilities of ileal amino acids between warm- and coldpressed rapeseed cakes, except for phenylalanine, which was higher in the former $(\mathrm{P}<0.05)$. The determined apparent ileal amino acid digestibilities are within the range reported in the literature for rapeseed meal (Fan and Sauer 1995), but slightly higher than those reported for fullfat rape seeds (Fan et al. 1995).

\section{Conclusions}

The present study shows that there is little variation in the chemical composition of organically grown pea and field bean cultivars. Protein quality in terms of the concentrations of essen- 


\section{Partanen, K. et al. Organically grown legume seeds and conventional rapeseed cakes for pigs}

tial amino acids, with the exception of arginine, decreased in peas as the protein level increased. Field bean protein contained smaller amounts of essential amino acids than did pea protein. Predicted on the basis of the in vitro enzymatic digestibility of dry matter and nitrogen, ileal nitrogen and amino acid digestibilities were similar in all pea cultivars. Predicted digestibilities were lower in field beans than in peas, particularly for sulphur-containing amino acids and energy. The apparent ileal digestibilities of lysine and threonine were similar in leafed and semileafless peas, field beans and sweet lupins. The ileal digestibility of methionine was low in all legume seeds, particularly in field beans. The apparent ileal digestibilities of amino acids, except phenylalanine, were similar in warm- and cold-pressed rape seed cakes.

Acknowledgements. This research was financially supported by the Ministry of Agriculture and Forestry in Finland. The authors wish to thank Mr. Markku Niskanen, MTT Agrifood Research Finland, for providing the pea samples and Kankaisten Öljykasvit Ltd. for providing the rapeseed cake. The staff of Animal Nutrition, MTT Agrifood Research Finland, is acknowledged for the care of experimental animals and laboratory analyses.

\section{References}

AOAC 1990. Official Methods of Analysis. Association of Official Analytical Chemists, Inc., Arlington, VA. 1298 p. ISBN 0-935584-42-0.

Bach Knudsen, K.E., Åman, P. \& Eggum, P.O. 1987. Nutritive value of Danish grown barley varietes. I. Carbohydrates and other major constituents. Journal of Cereal Science 6: 173-186.

Boisen, S. \& Fernández, J.A. 1995. Prediction of the apparent ileal digestibility of protein and amino acids in feedstuffs and feed mixtures for pigs by in vitro analyses. Animal Feed Science and Technology 51: 2943.

- \& Fernández, J.A. 1997. Prediction of total tract digestibility of energy in feedstuffs and pig diets by in vitro analyses. Animal Feed Science and Technology 68: 277-286.

Brufau, J., Boros, D. \& Marquardt, R.R. 1998. Influence of growing season, tannin content and autoclave treatment on the nutritive value of near-isogenic lines of faba beans (Vicia faba L.) when fed to leghorn chicks. British Poultry Science 39: 97-105.

Casey, R., Domoney, C. \& Smith, A.M. 1993. Biochemistry and molecular biology of seed products. In: Casey, R. \& Davies, D. R. (eds.) Peas: Genetics, molecular biology and biotechnology. Oxon: CAB International. p. 121-153. ISBN 0-85198-863-6.

Castell, A.G. \& Cliplef, R.L. 1993. Evaluation of pea screenings and canola meal as a supplementary protein source in barley-based diets fed to growing-finishing pigs. Canadian Journal of Animal Science 73: 129-139.

Cone, J.W. \& van der Poel, F.B. 1993. Prediction of apparent ileal protein digestibility in pigs with a twostep in-vitro method. Journal of the Science of Food and Agriculture 62: 393-400.
Davis, A. \& Hall, W.B. 1969. Cyclic change-over designs. Biometrika 56: 283-293.

EC 1998. Commission Directive 98/64/EC of 3 September 1998 establishing Community methods of analysis for the determination of amino acids, crude oils and fats, and olaquindox in feeding stuffs and amending Directive 71/393/EEC. Official Journal of European Commission L257: 14-28.

- 1999. Council Regulation (EC) No 1804/1999 of 19 July 1999 supplementing Regulation (EEC) No 2092/ 91 on organic production of agricultural products and indicators referring thereto on agricultural products and foodstuffs to include livestock production. Official Journal of European Commission L257: 1-28.

Fan, M.Z. \& Sauer, W.C. 1994. Amino acid and energy digestibility in peas (Pisum sativum) from white-flowered spring cultivars for growing pigs. Journal of the Science of Food and Agriculture 64: 249-256.

- \& Sauer, W.C. 1995. Determination of apparent ileal amino acid digestibility in barley and canola meal for pigs with the direct, difference, and regression methods. Journal of Animal Science 73: 2364-2374.

- \& Sauer, W.C. 1999. Variability of apparent ileal amino acid digestibility in different pea samples for growing-finishing pigs. Canadian Journal of Animal Science 79: 467-475.

-, Sauer, W.C. \& de Lange, C.F.M. 1995. Amino acid digestibility of soybean meal, extruded soybean and full-fat canola for early-weaned pigs. Animal Feed Science and Technology 52: 189-203.

Fernández, J.A. \& Batterham, E.S. 1995. The nutritive value of lupin-seed and dehulled lupin-seed meals as protein sources for growing pigs as evaluated by different techniques. Animal Feed Science and Technology 53: 279-296. 
Vol. 10 (2001): 309-322.

Gatel, F. 1994. Protein quality of legume seeds for nonruminant animal: a literature review. Animal Feed Science and Technology 45: 317-248.

- \& Grosjean, F. 1990. Composition and nutritive value of peas for pigs: a review of European results. Livestock Production Science 26: 155-175.

Gdala, J., Buraczewska, L. \& Grala, W. 1992. The chemical composition of different types and varieties of pea and the digestion of their protein in pigs. Journal of Animal and Feed Sciences 1: 71-79.

Helander, E., Näsi, M. \& Partanen, K. 1996. Effects of supplementary Aspergillus niger phytase on the availability of plant phosphorus, other minerals and nutrients in growing pigs fed on high-pea diets. Journal of Animal Physiology and Animal Nutrition 76: 6679.

Igbasan, F.A., Guenter, W. \& Slominski, B.A. 1997. Field peas: Chemical composition and energy and amino acid availabilities for poultry. Canadian Journal of Animal Science 77: 293-300.

Järvi, A., Kangas, A., Laine, A., Niskanen, M., Salo, Y., Vuorinen, M., Jauhiainen, L., \& Mäkelä, L. 2000. Virallisten lajikekokeiden tulokset 1992-1999. Maatalouden tutkimuskeskuksen julkaisuja, Sarja A 70. $216 \mathrm{p}$.

Jondreville, C., Grosjean, F., Buron, G., Peyronnet, C. \& Beneytout, J.L. 1992. Comparison of four pea varieties in pig feeding through digestibility and growth performance results. Journal of Animal Physiology and Animal Nutrition 68: 113-122.

Keith, M.O. \& Bell, J.M. 1991. Composition and digestibility of canola press cake as a feedstuff for use in swine diets. Canadian Journal of Animal Science 71: 879-885.

Le Guen, M.P., Huisman, J. \& Verstegen, M.W.A. 1995. Partition of the amino acids in ileal digesta from piglets fed pea protein diets. Livestock Production Science 44: 169-178.

Luh Huang, C. \& Schulte, E.E. 1985. Digestion of plant tissue for analysis by ICP emission spectrometry. Communications in Soil Science and Plant Analysis 16: 943-958.

Mehto, U. 1986. Siementuotannossa vielä ongelmia. Lupiinin viljely mahdollista Suomessakin. Koetoiminta ja käytäntö 43: 1

Niskanen, M. 2000. Lajikkeiden soveltuvuus luomuviljelyyn. In: Kinnunen, K. \& Teräväinen, H. (eds.). Luomusiemen- ja -taimiopas. Tieto tuottamaan 88. Maaseutukeskusten liitto. p. 27-38. ISBN 951-808-085-2.

Nyström, R., Pastuzewska, B., Buraczewska, L., Tulisalo, U. \& Ochtabinska, A. 1996. Effects of pressing technology of oil separation and heat treatment on the protein value of low-glucosinolate rape seed cake for non-ruminants. Journal of Animal and Feed Sciences 5: 235-248.

SAS 1998. SAS/STAT User's Guide (Release 6.03). SAS Institute, Inc., Cary, NC. 1686 p.

Savage, G.P. \& Deo, S. 1989. The nutritional value of peas (Pisum sativum). A literature review. Nutrition Abstracts and Reviews (Series A) 59: 65-87.

Schöne, F., Kirchheim, U., Schumann, W. \& Lüdke, H. 1996. Apparent digestibility of high-fat rapeseed press cake in growing pigs and effects on feed intake, growth and weight of thyroid and liver. Animal Feed Science and Technology 62: 97-110.

Snedecor, G.W. \& Cochran, W.G. 1989. Statistical Methods. Ed. 8, lowa State University Press, Ames. 503 p. ISBN 0-8138-1561-6.

Tuori, M., Kaustell, K., Valaja, J., Aimonen, E., Saarisalo, E. \& Huhtanen, P. 1996. Rehutaulukot ja ruokintasuositukset. Helsinki: Yliopistopaino. 92 p. ISBN 951-45-7348-X.

Udèn, P., Colucci, P.E. \& van Soest, P.J. 1980. Investigation of chromium, cerium and cobalt as digesta flow markers in rate of passage studies. Journal of the Science of Food and Agriculture 31: 625-632.

Valaja, J., Partanen, K., Siljander-Rasi, H., Jalava, T. \& Vasara, A. 1999. Effect of barley volume-weight on the apparent digestibility and utilisation of protein in growing pigs. In: Lobley, G.E. et al. (eds.). Protein metabolism and nutrition. Book of Abstracts of the 8th International Symposium on protein Metabolism and Nutrition. Wageningen Pers, Aberdeen, UK. p. 46.

van Barneveld, R.J. 1999. Understanding the nutritional chemistry of lupin (Lupinus spp.) seed to improve livestock production efficiency. Nutritional Research Reviews 12: 203-230.

van Kleef, D.J., Deuring, K. \& van Leeuwen, P. 1994. A new method of faeces collection in the pig. Laboratory Animals 28: 78-79.

van Leeuwen, P., van Kleef, D.J., van Kempen, G.J.M., Huisman, J. \& Verstegen, M.W.A. 1991. The postvalve T-caecum cannulation technique in pigs applicated to determine the digestibility of amino acid in maize, groundnut and sunflower meal. Journal of Animal Physiology and Animal Nutrition 65: 183-193.

Wasilewko, J. \& Buraczewska, L. 1999. Chemical composition including content of amino acids, minerals and alkaloids in seeds of three lupin species cultivated in Poland. Journal of Animal and Feed Sciences 8: $1-12$.

Williams, C.H., David, D. \& Riismaa, O. 1962. The determination of chromic oxide in faeces samples by atomic absorption spectrometry. Journal of Agricultural Science, Cambridge 59: 381-385. 


\title{
SELOSTUS
}

\section{Palkoviliojen ja rypsipuristeiden koostumus, aminohappojen ohutsuolisulavuus sekä rehuarvo sikojen ruokinnassa}

\author{
Kirsi Partanen, Jarmo Valaja, Taina Jalava ja Hilkka Siljander-Rasi \\ MTT (Maa- ja elintarviketalouden tutkimuskeskus)
}

Kahdeksasta luonnonmukaisesti viljellystä herne(Pisum sativum) ja kahdesta härkäpapulajikkeesta (Vicia faba) määritettiin kemiallinen koostumus sekä typen ja orgaanisen aineen in vitro -sulavuudet, joiden perusteella estimoitiin aminohappojen näennäiset ohutsuolisulavuudet ja energian kokonaissulavuus in vivo. Herneissä oli raakavalkuaista (RV) 244279 g/kg kuiva-ainetta (KA) ja härkäpavuissa 320$347 \mathrm{~g} / \mathrm{kg}$ KA. Herneissä raakarasvapitoisuus pieneni ja raakakuitupitoisuus suureni raakavalkuaispitoisuuden suuretessa. Useiden välttämättömien aminohappojen pitoisuus valkuaisessa pieneni valkuaispitoisuuden kasvaessa. In vitro -sulavuuksien perusteella ennustetut in vivo -sulavuudet vaihtelivat hernelajikkeiden välillä vähän, eikä sulavuuksien ja kemiallisen koostumuksen välillä ollut yhteyttä. Sulavuudet olivat pavuissa pienempiä kuin herneissä, erityisesti rikkipitoisten aminohappojen ohutsuolisulavuus ja energian kokonaissulavuus.

Sulavuuskokeessa oli kuusi ohutsuolikanyloitua leikkosikaa $(39-93 \mathrm{~kg})$. Koe tehtiin $6 \times 5$ syklisenä jaksokokeena. Kokeessa määritettiin luonnonmukaisesti tuotetun lehdellisen (lajike Sohvi, $199 \mathrm{~g} \mathrm{RV} / \mathrm{kg}$
KA) ja puolilehdettömän herneen (lajike Karita, $240 \mathrm{~g} \mathrm{RV} / \mathrm{kg} \mathrm{KA}$ ), härkäpavun (lajike Kontu, $320 \mathrm{~g}$ $\mathrm{RV} / \mathrm{kg} \mathrm{KA}$ ) ja sinilupiinin (Lupinus angustifolius lajike Pershatsvet, 220 g RV/kg KA) sekä tavanomaisesti tuotettujen lämmin- ja kylmäpuristetun rypsin ravintoaineiden kokonaissulavuudet ja aminohappojen näennäiset ohutsuolisulavuudet. Palkoviljojen lysiinin, treoniinin ja histidiinin ohutsuolisulavuudet olivat hyvin samanlaisia. Suurimmat erot olivat metioniinin ja kystiinin sulavuuksissa. Lupiinin arginiinin, isoleusiinin, valiinin ja useimpien ei-välttämättömien aminohappojen ohutsuolisulavuudet olivat parhaimmat ja härkäpavun huonoimmat, herneen aminohappojen ohutsuolisulavuuksien asettuessa näiden välille. Aminohappojen näennäiset ohutsuolisulavuudet olivat samanlaisia rypsipuristeissa, paitsi fenyylialaniinin sulavuus, joka oli pienempi lämpökäsitellyssä kuin kylmäpuristetussa rypsipuristeessa. Lehdellisessä ja puolilehdettömässä herneessä oli nettoenergiaa 10,8 ja 11,2 MJ, härkäpavussa 9,8 MJ, lupiinissa 9,7 MJ ja rypsipuristeissa 9,4 and 12,3 MJ/ $\mathrm{kg}$ KA. 